\title{
TECHNOLOGIE REGULACYJNE SZANSA NA OBNIŻENIE KOSZTÓW COMPLIANCE
}

\section{WSTĘP}

Koszty compliance, które odnoszą się do wszystkich nakładów pieniężnych ponoszonych przez przedsiębiorstwa w celu przestrzegania określonych regulacji, sa jednym z ważniejszych elementów w procesie optymalizacji wydatków regulacyjnych. Co do zasady koszty te rosna wraz ze wzrostem regulacji w danej branży. Koszty compliance generowane sa przez akty prawne o charakterze międzynarodowym, krajowym, lokalnym oraz tzw. miękkie prawo. Międzynarodowe przedsiębiorstwa, do których zalicza się w większości instytucje finansowe, podlegają znacznej ilości regulacji w stosunku do przedsiębiorstw lokalnych działających w lokalnych jurysdykcjach państwowych. Ponadto od 2007 r. sektor finansowy zmaga się z postępujaca inflacją prawa finansowego. Głównymi przyczynami masowej produkcji prawa finansowego jest spadek zaufania do sektora finansowego wywołanego kryzysem z lat 2007-2009, wzrostem znaczenia nowych technologii w finansach oraz zjawiskiem shadowbanking. W praktyce wzrost inflacji prawa finansowego oznacza wyższe ryzyko regulacyjne instytucji finansowych, co przekłada się na większe nakłady ponoszone w celu przystosowania swoich modeli biznesowych do obowiazujących norm prawnych lub w przypadku braku adaptacji swoich działań do przepisów - danin na rzecz państwa w postaci nałożonych kar pieniężnych. Jednym z narzędzi umożliwiających sprawne zarządzanie ryzykiem braku zgodności z procesami biznesowymi danego przedsiębiorstwa jest compliance managment system (CMS). Obecnie CMS podlega dynamicznym zmianom. Przedmiotowe zmiany zostały wywołane przez rozwiązania spółek zajmujących się technologiami regulacyjnymi (RegTech).

Celem artykułu jest przedstawienie rozwiązań RegTech i możliwości ich zastosowania w kontekście optymalizacji kosztów compliance. Wskazano w nim również na podstawowe obszary wpływające na wzrost ryzyka regulacyjnego - rozwój sektora financial technology (FinTech), czyli usług finansowych opartych na wysoko zaawansowanych technologiach, oraz shadow banking. Przedstawiono również konsekwencje prawne związane z brakiem zapewnienia przez zarządzających zgodności z obowiązującymi regulacjami. Rozważania dotyczące kosztów compliance obejmują aktualną sytuację na rynkach finansowych ze szczególnym uwzględnieniem sektora FinTech. Zaprezentowano dane obejmujące działania Komisji Nadzoru Finansowego dotyczące wiel- 
kości sankcji nałożonych na podmioty rynku finansowego w 2016 r. Omówiono również wpływ poszczególnych technologii na sposób zarządzania ryzykiem compliance. Podjęto próbę zdefiniowania technologii regulacyjnych oraz zaprezentowano kluczowe obszary powiązane z rozwiązaniami RegTech.

\section{INFLACJA PRAWA FINANSOWEGO, SHADOW BANKING I NOWE TECHNOLOGIE JAKO ISTOTNE ŹRÓDLO RYZYKA COMPLIANCE}

Od początku kryzysu 2007-2009 stwierdzono znaczny wzrost regulacji obejmujaccych sektor finansowy. Liberalizacja usług finansowych została znacznie ograniczona. Najnowsze badania przedstawione w raporcie OECD ${ }^{1}$ potwierdzają tę tezę. W głównej mierze regulacje finansowe są odpowiedzią na sytuacje kryzysowe przybierające postać planów ratunkowych mających za zadanie złagodzić destabilizację gospodarczą ${ }^{2}$. Tym samym większość państw mija się z głównym celem dobrych regulacji, które powinny spełniać funkcje prewencyjna - działać wyprzedzająco na możliwość wystapienia określonego ryzyka. Skala masowego kreowania regulacji finansowych wdrażanych w szybkim tempie, bez odpowiedniej vactio legis i bez zachowania w procesie tworzenia prawa zasady proporcjonalności ${ }^{3}$, skutkuje szeregiem negatywnych zjawisk dla podmiotów obrotu gospodarczego z branży finansowej. Instytucje finansowe często wskazują na brak dialogu z ustawodawcą w procesie konsultacyjno-legislacyjnym. Z raportu ${ }^{4}$ firmy Grant Thornton wynika, że 40\% projektów ustaw pozostaje bez merytorycznej analizy w komisjach sejmowych, a w przypadku $70 \%$ projektów - konsultacje w komisjach maja swój koniec między I a II czytaniem w Sejmie. Brak transparentności podczas tworzenia aktów prawnych prowadzi do niespójności przepisów, często korygowanych za pomocą aktów nowelizujących lub aktów delegowanych.

Zauważano również wzrost zaangażowania organów regulacyjnych wydających interpretacje w postaci zaleceń czy opinii przybierających postać miękkiego prawa (soft law). Oczywiście soft law nie stanowi prawa powszechnie obowiazującego i często podmioty gospodarcze odwołują się do sądów powszechnych, powołując się na niezgodność wytycznych organów nadzoru z powszechnie obowiąującym prawem. Inne negatywne konsekwencje tworzenia prawa bez zachowania odpowiednich procedur przybieraja postać rozbudowanej biurokracji państwowej, rozmycia odpowiedzialności organów administracji publicznej

${ }^{1}$ O. Denk, G. Gomes, Financial re-regulation since the global crisis?: An index-based assessment, „OECD Economics Department Working Papers”, No. 1396, OECD Publishing, Paris 2017.

${ }^{2}$ M. Brol, Regulacje publiczne w dobie kryzysu gospodarczego, „Ekonomia i Prawo” 6, 2010, s. 219 .

${ }^{3}$ S. Kasiewicz, L. Kurkliński, W. Szpringer, Zasada proporcjonalności. Przełom $w$ ocenie regulacji, Alterum, Warszawa 2014.

${ }^{4}$ Grant Thornton, Produkcja prawa $w$ Polsce spowolnita, ale nadal przyttacza. Barometr stabilności otoczenia prawnego w polskiej gospodarce, edycja 2018. 
oraz niechęci podmiotów gospodarczych do podejmowania strategicznych decyzji biznesowych z uwagi na niepewność otoczenia regulacyjnego. Niepokojącym zjawiskiem towarzyszacym inflacji prawa jest arbitraż regulacyjny wynikający zazwyczaj z braku spójności przepisów prawnych. Ważną kwestią jest również ocena skutków regulacji zarówno w ujęciu ex ante, jak i ex post ${ }^{5}$, stanowiąca swoisty bufor bezpieczeństwa przed nadmierną i nieuzasadniona legislacją ${ }^{6}$.

Istotnym aspektem regulacji rynków finansowych jest złożoność ich uczestników. Podmioty rynku finansowego działają nie tylko jako instytucje finansowe objęte nadzorem państwowym, ale również jako podmioty systemu bankowości cienia (shadow banking) ${ }^{7}$. Aprecjacji równoległemu systemowi bankowemu sprzyja ostatnio scalanie określonych sektorów gospodarki z innymi gałęziami biznesu na poziomie globalnym, powodujac tym samym powstawanie zupełnie nowych struktur prowadzenia działalności gospodarczej na rynkach finansowych - np. spółki motoryzacyjne tworzą swoje banki, banki oferuja usługi związane z ochrona zdrowia lub spersonalizowanym przetwarzaniem danych klientów, a spółki technologiczne prowadzą działalność pośrednictwa kredytowego czy też same w ramach platform internetowych tworzą kredytowanie typu peer-to-peer lending. Postępująca konwergencja określonych sektorów gospodarki z innym gałęziami gospodarki skutkuje wzmożonym wykorzystaniem rozwiąań outsourcingu. Tego typu działania komplikuja kwestie odpowiedzialności prawnej podmiotów gospodarczych. Ponadto równoległy system bankowy przez swoja „elastyczność” wykorzystuje arbitraż prawny i nie podlega instytucjom regulacyjno-nadzorczym. Polityka tworzenia jednolitych struktur unijnych ${ }^{89}$, koncepcja open-banking ${ }^{10}$ oraz zmiany regulacyjne (dyrektywa PSD $2^{11}$ ) zwiększaja możliwości rozwoju nieznanych do tej pory form prowadzenia działalności biznesowej, determinując tym samym stosowanie rozwiązań outsourcingowych z flagowymi podmiotami na czele - typu FinTech, czyli usług finansowych opartych na wysoko zaawansowanych technologiach.

${ }^{5}$ W. Szpringer, W. Rogowski, Ocena skutków regulacji: poradnik OSR, doświadczenia, perspektywy, Warszawa 2007.

${ }^{6}$ Np. ustawa z 14 kwietnia 2016 r. o wstrzymaniu sprzedaży nieruchomości Zasobu Własności Rolnej Skarbu Państwa oraz o zmianie niektórych ustaw, która w głównej mierze miała poprawić sytuację polskich rolników, a w rzeczywistości doprowadziła do pogorszenia ich zdolności kredytowej, czego efektem była nowelizacja ustawy. Więcej na ten temat: K. Mórawski, Obrót ziemiq rolnq: squpowody do optymizmu, <https://alebank.pl/prawo=-obrot-ziemia-rolna-sa-powody-do-optymizmu/?id242838\&catid=26173> [dostęp: 16.02.2018].

${ }^{7}$ W. Szpringer, Fin-Tech - nowe zjawisko na rynku ustug finansowych, „e-mentor” 2016, nr 2(64), s. 56-69.

8 A. Janc, P. Mikołajczak, P. Waliszewski, Europejska Unia Rynków Kapitałowych. Perspektywa finansowania przedsiębiorstw w Polsce, Warszawa 2015.

${ }^{9}$ T. Nieborak, Unia Rynków Kapitałowych UE - jako kolejny etap federalizacji rynku finansowego Unii Europejskiej?, w: J. Gliniecka et al. (red.), Praktyczne i teoretyczne problemy prawa finansowego wobec wyzwań XXI wieku, Warszawa 2017, s. 491-500.

${ }^{10}$ Introducing the Open Banking Standard, Open Data Institute 2016.

${ }_{11}$ Dyrektywa Parlamentu Europejskiego i Rady (UE) 2015/2366 z 25 listopada 2015 r. w sprawie usług płatniczych w ramach rynku wewnętrznego, zmieniająca dyrektywy 2002/65/WE, 2009/110/WE, 2013/36/UE i rozporządzenie (UE) nr 1093/2010 oraz uchylająca dyrektywę 2007/64/WE. 
Równolegle z początkiem kryzysu finansowego rozpoczął się znaczny udział nowych technologii w sektorze finansowym. Przełom technologiczny nazywany również trzecią rewolucją cywilizacyjna - obok agrarnej i przemysłowej - doprowadził do znacznej rewizji współczesnych form prowadzenia biznesu przez instytucje finansowe. Na rynku pojawiły się firmy, które dzięki zastosowaniu w swoich modelach biznesowych innowacyjnych rozwiązań IT - stworzyły nowe produkty oparte na pionierskim podejściu w procesie przetwarzania i analizie danych. Połączenie danych finansowych oraz wykorzystanie współczesnych technologii IT typu: big data, blockchain, protokół API ${ }^{12}$ (application programming interface) cloud computing, zwłaszcza model SaaS, biometria, maschine learning, artifcial intelligence stworzyły podmioty gospodarcze określane jako spółki FinTech ${ }^{13}$. Przewaga technologiczna tego typu firm oraz brak kosztownego otoczenia regulacyjnego, a z drugiej strony zapotrzebowanie podmiotów FinTech na dostęp do szczegółowych danych finansowych stwarza naturalną symbiozę współpracy, przy wymianie informacji oraz oferowania wspólnych usług docelowym konsumentom we współpracy z instytucjami finansowymi. Wskazuje się, że do głównych czynników decydujących o sukcesie FinTech należą: niskie marże, brak konieczności inwestowania w drogie aktywa, innowacyjność, łatwa skalowalność, optymalizacja przestrzegania prawa (compliance) ${ }^{14}$. Rosnąca popularność smartfonów, nieefektywne, tradycyjne system finansowania oraz zmiany zachowania konsumentów (pokolenia Y) mogą stanowić podatny grunt dla rozwoju podmiotów FinTech. W większości spółki FinTech mają charakter spółek online, a rozwiązania SaaS umożliwiają im prowadzenie działalności bez ponoszenia dodatkowych kosztów na infrastrukturę i oprogramowanie do wytworzenia własnego software. Wykorzystanie technologii przetwarzania w chmurze oraz dostęp do niskokosztowej infrastruktury obliczeniowej powoduje tworzenie nowych ekosystemów. Do niedawna e-biznes ograniczał się do zamkniętych ekosystemów, tworząc zasadniczo jeden łańcuch powiązań. Dzięki protokołowi API oraz koncepcji skalowania systemów ludzkość może znaleźć się w zupełnie nowej rzeczywistości.

Zjawisko cyfryzacji społeczeństwa stało się faktem. Budowa różnych ekosystemów informatycznych dostarczyła nowych sposobów na prowadzenie biznesu. Gospodarka oparta na wiedzy i przetwarzaniu informacji na stałe wpisała się w obraz globalnej ekonomii. Katalizatorem zachodzacych zmian sa kluczowe technologie wdrażane w określonych modelach biznesowych. $\mathrm{Na}$ podstawie analiz ${ }^{15}$ przeprowadzonych przez firmę konsultingową Gart-

12 M. Ciesielski, Otwarta bankowość dzięki API, <https://www.obserwatorfinansowy.pl/tematyka/bankowosc/otwarta-bankowosc-dzieki-api/ >[dostęp: 20.07.2017].

${ }^{13}$ W. Szpringer, Nowe technologie a sektor finansowy. FinTech jako szansa i zagrożenie, Warszawa 2017.

${ }^{14}$ W. Rogowski, Regulacje finansowe. FinTech - nowe instrumenty finansowe - resolution, Warszawa 2017.

15 Smarter With Gartner, Top Trends in the Gartner Hype Cycle for Emerging Technologies, 2017. 
ner w najbliższych latach blockchain ${ }^{16}$, sztuczna inteligencja ${ }^{17}$ oraz rzeczywistość rozszerzona ${ }^{18}$ (augmented reality) staną się istotnymi narzędziami prowadzenia np. e-biznesu - zwłaszcza w sektorze finansowym.

Wraz ze zmianami sposobu prowadzenia działalności finansowej, nadmiernymi regulacjami oraz fragmentaryzacją uczestników rynków finansowych (third party payment service provider ${ }^{19}$ ) rośnie ryzyko compliance. Compliance oznacza przestrzeganie przez przedsiębiorstwo wiążących je norm prawnych oraz wytycznych w postaci miękkiego prawa, które go dotycza. Na gruncie prawa polskiego brakuje przepisów, z których wynikałby obowiązek stosowania procedur zgodności. Wydaje się jednak, że polskie przedsiębiorstwa będą skazane na tworzenie odpowiednich systemów zarządzania ryzykiem dopasowanych odpowiednio do swoich modeli biznesowych; takie regulacje, jak: rozporządzenie RODO oraz dyrektywa AML IV, dotyczą każdego przedsiębiorcy prowadzącego działalność gospodarcza w Polsce. Widmo kary przewidziane w rozporządzeniu RODO skutecznie może mobilizować przedsiębiorców do stosowania odpowiednich procedur compliance.

Brak zgodności z regulacjami może narazić organy instytucji finansowej oraz samą instytucję finansową na odpowiedzialność cywilna, administracyjną i karną. Większość instytucji finansowych prowadzi działalności w postaci spółek prawa handlowego. W razie niedopełnienia obowiązku przez spółkę lub wykonania nieprawidłowo określonej czynności, przewidzianej przepisami prawa - w pierwszej kolejności roszczenia cywilnoprawne oraz kary pieniężne będa kierowane w stronę spółki. W drugiej kolejności poszukuje się konkretnych osób (członkowie zarządu, rady nadzorczej, dyrektorzy departamentów), które mogą odpowiadać za swoje działanie lub zaniechanie w związku z niewykonaniem lub nienależytym wykonaniem określonego obowiązku. Odpowiedzialność właścicieli spółki oraz osób prowadzącej jej sprawy jest oparta na kryterium starannego kupca oraz dobrego menadżera. Ostatnie kryterium stosuje się w głównej mierze do osób prowadzacych sprawy spółki (np. prokurentów). Zgodnie z przepisami Kodeksu cywilnego oraz Kodeksu spółek handlowych istota działania menagerów jest szczególny obowiązek działania w interesie spółki i dochowania wszelkiej należytej staranności w kierowaniu osobą prawna.

Należyta staranność jest oceniana przede wszystkim z perspektywy zawodowego charakteru wykonywanej działalności i pełnionych funkcji. Istnieje domniemanie prawne, że osoba wykonująca w imieniu spółki określone obowiązki i działania na jej rzecz posiada niezbędne kwalifikacje i uprawnienia (np. makler papierów wartościowych, broker ubezpieczeniowy, radca prawny). Brak należytej staranności nawet w sposób nieumyślny może spowodować poważne konsekwencje dla osób prowadzących sprawy spółki. Często brak czujności oraz dokładności w realizacji powierzonych zadań stanowi samodzielna

16 E. Ślązak, Jak działa blockchain, „Gazeta Bankowa” 2018, nr 3; J. Czarnecki. Blockchain a prawo, 2015, <http://prawo.io/blockchain-a-prawo/> [dostęp: 14.09.2015].

17 The Economist Newspaper Limited, <https://www.obserwatorfinansowy.pl/tematyka/ bankowosc/sztuczna-inteligencja-wkracza-w-swiat-finansow/> [dostęp: 18.06.2017].

${ }^{18}$ E. Ślązak, Wirtualna rzeczywistość w ustugach finansowych, <https://www.viem.pl/pl/twojefinanse/wirtualna-rzeczywistosc-ang-virtual-reality-w-uslugach-finansowych> [dostęp: 10.10.2017].

${ }_{19}$ W. Szpringer, M. Szpringer, Nowe zjawiska w regulacji rynku usług płatniczych (wybrane problemy na tle projktu noweli do dyrektywa PSD), ,e-mentor” 2014, nr 4(56), s. 73-83. 
przesłankę popełnienia przestępstwa, np. nadużycia zaufania. Odpowiedzialność karna osób prowadzących sprawy spółki może być również następstwem nieprawidłowości, których dopuścili się pracownicy danej organizacji. Liczba obowiązków prawnych wynikających z określonych regulacji, a co za tym idzie, ryzyka zgodności, kreuje potrzebę wprowadzenia w rozbudowanych instytucjach finansowych narzędzi typu compliance ${ }^{20}$. Przykładowo w raporcie Fundacji FinTech Poland ${ }^{21}$ wskazano aktualnie 47 najważniejszych obowiązków instytucji finansowych, wynikających z różnych ustaw ${ }^{22} \mathrm{w}$ kontekście działalności spółek sektora FinTech i zniesienia barier rozwoju tego sektora. Sankcje za naruszenie określonych norm prawnych są wysokie. Zgodnie ze sprawozdaniem $^{23}$ KNF za 2016 r. organ nadzoru nałożył w ramach decyzji administracyjnej 336 kar pieniężnych oraz 4 kary pieniężne wraz z wykluczeniem akcji emitenta z obrotu na rynku regulowanym. Łączna wysokość kar w 2016 r. nałożonych przez KNF na podmioty rynku finansowego wyniosła 11549900 zł.

\section{Tabela 1}

Udział podmiotów rynku finansowego w karach nałożonych przez KNF w 2016 r.

\begin{tabular}{|l|r|r|}
\hline \multicolumn{1}{|c|}{ Podmiot } & $\begin{array}{c}\text { Wartość } \\
\text { kary }\end{array}$ & \multicolumn{1}{c|}{ Udzial } \\
\hline Emitenci (I instancja) & 6520000 & $56,45 \%$ \\
\hline Akcjonariusze lub inne osoby fizyczne & 2120000 & $18,36 \%$ \\
\hline Członkowie zarządów spółek publicznych & 1535000 & $13,29 \%$ \\
\hline Firmy inwestycyjne & 425000 & $3,68 \%$ \\
\hline Towarzystwa funduszy inwestycyjnych & 250000 & $2,16 \%$ \\
\hline Zakłady ubezpieczeń & 380000 & $3,29 \%$ \\
\hline Biura usług płatniczych & 234200 & $2,03 \%$ \\
\hline Pracodawcy prowadzących pracownicze programy emerytalne & 50000 & $0,43 \%$ \\
\hline Otwarte fundusze emerytalne & 30000 & $0,26 \%$ \\
\hline Brokerzy ubezpieczeniowi & 5700 & $0,05 \%$ \\
\hline Razem & 11549900 & $100,00 \%$ \\
\hline
\end{tabular}

Źródło: opracowanie własne na podstawie sprawozdania KNF z 2016 r.

${ }^{20}$ B. Jagura, Rola organów spótki kapitałowej w realizacji funkcji compliance, Warszawa 2017; B. Makowicz, Compliance w przedsiębiorstwie, Warszawa 2011; D. Jagiełł, Granice odpowiedzialności menedżera, „Edukacja Prawnicza” 2012, nr 2; P. Gołębiowski, Prawne aspekty funkcji compliance, „Prawo Bankowe” 2008, nr 9, s. 83-92, oraz „Prawo Bankowe” 2008, nr 10, s. $70-83$.

${ }^{21}$ RegTech. Znaczenie innowacji regulacyjnych dla sektora finansowego i państwa, Raport FinTech Poland 2017, s. 18-20.

${ }^{22}$ Ustawy: z 29 sierpnia 1997 r. - Prawo bankowe (Dz. U. 1997, Nr 140, poz. 939); z 29 sierpnia 1997 r. o Narodowym Banku Polskim (Dz. U. 2017, poz. 1373); z 19 sierpnia 2011 r. o usługach płatniczych (Dz. U. 2011, nr 199, poz. 1175); z 29 lipca 2005 r. w obrocie instrumentami finansowymi (Dz. U. 2005, Nr 183, poz. 1538).

${ }^{23}$ Sprawozdanie z działalności Komisji Nadzoru Finansowego w 2016 roku, s. 142-143, <https://www.knf.gov.pl/knf/pl/komponenty/img/Sprawozdanie\%20z\%20działalności\%20 KNF\%202016_58816.pdf> [dostęp: 5.06.2017]. 
W tym samym roku KNF skierowała do organów ścigania 54 zawiadomienia o uzasadnionym podejrzeniu popełnienia przestępstwa. $\mathrm{Z}$ roku na rok liczba zawiadomień się zmniejsza, co może świadczyć o efektywniejszym compliance instytucji finansowych ${ }^{24}$. Zdarzają się jednak poważne naruszenia ${ }^{25}$. Największa ilość naruszonych norm prawnych dotyczyła przepisów z ustawy o obrocie instrumentami finansowymi - manipulacja instrumentami finansowymi, ujawnieniem i wykorzystanie informacji poufnej, prowadzenie działalności maklerskiej bez wymaganego zezwolenia. $\mathrm{Na}$ podstawie złożonych zawiadomień wszczęto 50 postępowań przygotowawczych. W 2016 r. prokuratura postanowiła skierować do sąów powszechnych 9 aktów oskarżenia na podstawie zawiadomień zgłoszonych przez KNF. Z kolei wymiar sprawiedliwości wydał 13 wyroków skazujących oraz warunkowo umarzających postępowanie karne w następstwie zgłoszonych zawiadomień o uzasadnionym podejrzeniu przestępstwa przez KNF, jak również zgłoszone przez inne podmioty, w których przewodniczący KNF wystapił w charakterze pokrzywdzonego.

\section{SYSTEM ZARZĄDZANIA COMPLIANCE ORAZ KOSZTY COMPLIANCE NA PRZYKLADZIE SEKTORA BANKOWEGO}

Wdrożenie procedur CMS w zależności od wielkości instytucji finansowej jest przedsięwzięciem skomplikowanym i kosztownym, jednakże inwestycja tego typu powinna wpisać się na trwałe w struktury rzetelnego biznesu. Koszty związane z zapewnieniem zgodności z obowiązującymi regulacjami są znaczącym obciążeniem dla instytucji finansowych. Zgodnie z przeprowadzonymi analizami Instytutu Compliance wynika, że polscy przedsiębiorcy nie potrafili jednoznacznie określić kosztów wdrożenia CMS w swoich organizacjach: $11 \%$ ankietowanych oszacowało wydatki na CMS powyżej $100000 \mathrm{zł}$, reszta odpowiedzi oscylowała między $5000 \mathrm{zł}$ a 50000 zł. Z kolei 56\% ankietowanych oceniło koszty inwestycyjne poniesione na CMS jako adekwatne do celów i funkcji compliance ${ }^{26}$. Warto również wskazać, że w większości przypadków kluczowe decyzje co do wdrożenia systemu CMS podejmuje zarząd firmy w kontekście własnego bezpieczeństwa (62\%) lub jest to narzucane odgórnie przez zagraniczną spółkę-matkę (46\%).

24 Ibidem, s. 143.

25 Ewidentnym przykładem łamania prawa oraz zaprezentowania negatywnego efektu braku wdrożenia lub ignorowania compliance była sprawa FinCrea TFI - Komunikat KNF w sprawie FinCrea Towarzystwa Funduszy Inwestycyjnych SA, <https://www.knf.gov.pl/knf/pl/komponenty/img/Komunikat_KNF_ws\%20_FinCrea_TFI_SA.pdf $>$ [dostęp: 22.11.2017].

${ }^{26}$ Compliance $w$ Polsce, Raport $z$ badania stanu compliance $i$ systemów zarzadzania zgodnościa $w$ działajacych $w$ Polsce przedsiębiorstwach, Instytut Compliance we współpracy z EY, Wolters Kluwer oraz Viadrina Compliance Center działającym na Uniwersytecie Europejskim Viadrina we Frankfurcie nad Odra, s. 31. 
$\mathrm{Na}$ trzecim miejscu czynnikiem determinującym są wymogi ustawowe lub inne wymogi formalne, np. rynki regulowane $(38 \%)^{27}$.

Zgodnie z wytycznymi OECD ${ }^{28}$ koszty compliance zaliczane sa do kosztów regulacyjnych, obok kosztów finansowych czy pośrednich (schemat 1).

\section{Schemat 1}

Podział kosztów regulacyjnych

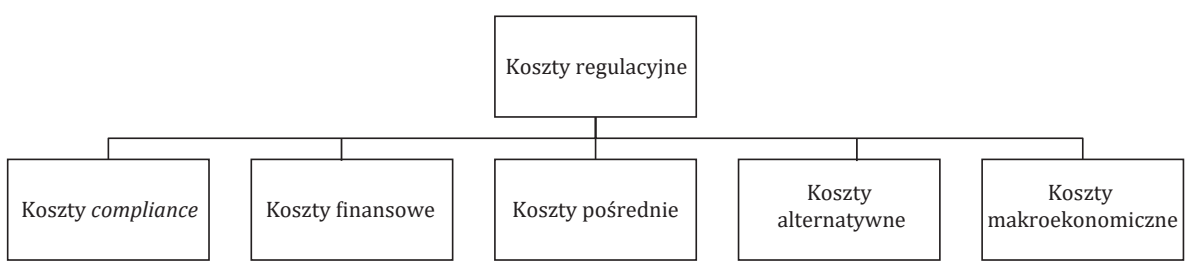

Źródło: opracowanie własne.

Koszty compliance to przede wszystkim wydatki poniesione w wyniku spełnienia wymogów prawnych narzuconych przez ustawodawcę. Do kosztów compliance można zaliczyć m.in. systemy informatyczne służące do zarządzania informacją na potrzeby raportowania, koszty personelu potrzebnego do monitorowania systemu zgodności oraz koszty tworzenia raportów i szkoleń personelu. Polski ustawodawca zgodnie z nowa ustawa z 6 marca 2018 r. Prawo przedsiębiorców (Dz. U. 2018, poz. 646) uwzględnił w rozdziale 6 przedmiotowej ustawy „Zasady opracowywania projektów aktów normatywnych z zakresu prawa gospodarczego oraz oceny ich funkcjonowania". W analizowanym rozdziale wprowadzono pojęcie oceny przewidywania skutków społeczno-gospodarczych określonych regulacji. Minister Finansów jest w trakcie przygotowania projektu rozporządzenia ${ }^{29}$ do ustawy, które ma unormować kwestie zwiąane z pomiarem i analizą kosztów regulacji. Przyjęte założenia będą stanowić novum w polskim systemie prawnym oraz niewątpliwie przyczynią się do stworzenia innego postrzegania wydatków poniesionych na compliance, co za tym idzie, przedsiębiorstwa będą zobowiązane do prowadzenia specjalnych ewidencji związanych z kosztami wydatkowanymi na zarządzanie ryzykiem compliance. Aktualnie polskie władze nie prowadzą dokładnych analiz kosztów zapewnienia zgodności.

Z kolei w USA od 2013 r. firma doradcza z branży Regulatory Operations Center of Continuity (RegAdvesory) tworzy Banking Compliance Index $(\mathrm{BCI})^{30}$. Indeks zgodności bankowej (BCI) jest to kwartalny wskaźnik śledze-

\footnotetext{
${ }^{27}$ Ibidem, s. 27.

${ }^{28}$ OECD, Regulatory Compliance Cost Assessment Guidance, OECD 2014, s. 11.

${ }^{29}$ Zob. <http://www.mf.gov.pl/documents/764034/5123672/8_Podrecznik_Liczenia_Kosztow_ Regulacyjnych.pdf> [dostęp: 18.11.2016].

${ }^{30} \mathrm{BCI}$ jest wykorzystywany jako wiarygodny wskaźnik referencyjny w publikacjach m.in. „The Economist”, WSJ, Bloomberg, American Banker, Independent Banker, Bank Innovation, "Credit Union Times”, „Credit Union Journal”, Mortgage News Daily i Reverse Mortgage Daily. Źródła danych BCI obejmuja: CFPB, FDIC, FED, NCUA i OCC. BCI oblicza się na podstawie średniej wielkości instytucji finansowej, której aktywa nie przekraczają 350 milionów dolarów.
} 
nia zmian regulacji. Mierzy on dodatkowe obciążenia finansowe instytucji finansowych w Stanach Zjednoczonych. Według indeksu BCI w IV kwartale 2016 r. średnia instytucja finansowa o aktywach 350 mln USD potrzebowała 2,16 dodatkowego miejsca pracy, aby wprowadzić dodatkowe przepisy związane $\mathrm{z}$ regulacjami. W wydatkach oznaczało to dodatkowe 53046 USD, zwiazanych z przestrzeganiem przepisów dotyczących sektora bankowego. W III kwartale wskaźnik zapotrzebowanie na nowe miejsca pracy wynosiły średnio 1,63, a w IV kwartale 2015 r. - 2,23. Pod koniec 2016 r. odnotowano 115 zmian regulacyjnych, które przełożyły się na 6057 stron w porównaniu z 77 zmianami, które przybrały postać ponad 2700 stron w poprzednim roku. W 2016 r. wprowadzono 334 zmiany w ustawodawstwie bankowym Stanów Zjednoczonych.

W raporcie Fundacji FinTech Poland oraz Centrum Prawa Nowych Technologii WPiA UW ${ }^{31}$ wskazano, że wydatki związane $\mathrm{z}$ wynagrodzeniami dla pracowników w sektorze compliance znacznie wzrosły. Przykładowo Bank of America w latach 2011-2014 podwoił zatrudnienie w obszarze audytu i zgodności. Z kolei CitiBank zatrudniał 30000 osób w dziale compliance, co stanowiło $13 \%$ personelu całej organizacji. To oznaczało wzrost zatrudnienia dla tej instytucji o ponad 33\% w porównaniu z 2011 r. JP Morgan Chase w 2010 r. zwiększył zatrudnienie w działach zapewnienia zgodności o 30\%. Według ostrożnych szacunków IBM organy regulacyjne tworzą obecnie co najmniej 20000 tys. wymogów regulacyjnych, a cały zbiór nowych przepisów przekroczy 300 mln stron do roku 2020, natomiast na podstawie danych Amerykańskiego Stowarzyszenia Bankowego w samych USA wydaje się rocznie około 70 mld na obsługę compliance ${ }^{32}$.

Powyższe dane świadcza, że problem compliance jest istotny z punktu widzenia zarządzania instytucją finansową i może generować znaczne koszty. Wymusza to na zarządzających odpowiednie podejście w procesie optymalizacji wydatków na zapewnienie zgodności z obowiązującymi przepisami. Redukcja kosztów zapewnienia zgodności ma charakter dwojaki. Optymalizację wydatków ponoszonych na cele compliance można podzielić na publiczne i prywatne. Do publicznych instrumentów oddziaływania na tworzenie prawa można zaliczyć ocenę skutków regulacji lub piaskownicę regulacyjną (sandbox) ${ }^{33}$, $\mathrm{z}$ kolei do prywatnych form optymalizacji w świetle nowych trendów - rozwiązania typu RegTech ${ }^{34}$.

${ }^{31}$ Raport RegTech - znaczenie innowacji regulacyjnych dla sektora finansowego i państw, Fundacja FinTech Poland oraz Centrum Prawa Nowych Technologii WPIA UW, 2017, s. 4.

${ }^{32}$ G.S. Bektenova, Are RegTech, FinTech, Blockchain the Future?, w: III Network AML/CFT Institute International Scientific and Research Conference „FinTech and RegTech: Possibilities, Threats and Risks of Financial Technologies”, KnE Social Sciences, 2018, s. 61.

${ }_{33}$ Sandbox, czyli piaskownica regulacyjna, jest zaliczana do instrumentów wspierających spółki FinTech. Głównym celem piaskownicy jest stworzenie „bezpiecznego środowiska”, w ramach którego podmioty gospodarcze będą mogły w ograniczony sposób testować swoje rozwiązania technologiczne, kierując je bezpośrednio do konsumentów rynku finansowego. Inaczej mówiąc, sandbox ma spełniać funkcje parasola ochronnego nad sektorem FinTech, a co za tym idzie, minimalizować ryzyko związane z wprowadzaniem nowych technologii do usług typu consumer finance oraz redukcji kosztów regulacyjnych dla początkujących przedsiębiorców.

${ }^{34} \mathrm{~K}$. Marchewka-Bartkowiak, Nowe rozwiazania regulacyjne - RIA, sandbox, compliance, RegTech - w świetle procesu „inflacji” prawa finansowego, „Studia Biura Analiz Sejmowych”, Warszawa 2018, s. 135-146. 


\section{RegTech - PROBLEMY DEFINICYJNE I MOŻLIWY WPLYW NA OBNIŻENIE KOSZTÓW COMPLIANCE}

Aktualnie próba zdefiniowania pojęcia RegTech może być trudna z uwagi na dynamiczne zmiany zachodzace w sektorze nowych technologii. Powszechnie uznaje się, że RegTech to osobny podmiot typu FinTech (spółka technologiczna) lub zbiór określonych narzędzi IT bazujących na nowych rozwiązaniach technologicznych. W świetle funkcji, którą spełnia, RegTech określa się go jako sposób wykorzystania technologii IT w celu monitorowania i raportowania regulacyjnego oraz zapewniania zgodności działań gospodarczych określonej instytucji finansowej z obowiąującymi przepisami prawa ${ }^{35}$. Do głównych cech RegTech można zaliczyć przejrzystość, spójność, standaryzację oraz efektywność w przestrzegania procesów regulacyjnych. Konkludując, RegTech odnosi się głównie do rozwiązań technologicznych usprawniających procesy compliance w sektorze finansowym. W literaturze podkreśla się, że RegTech jest kategorią segmentu spółek FinTech.

\section{Schemat 2}

RegTech jako segment FinTech

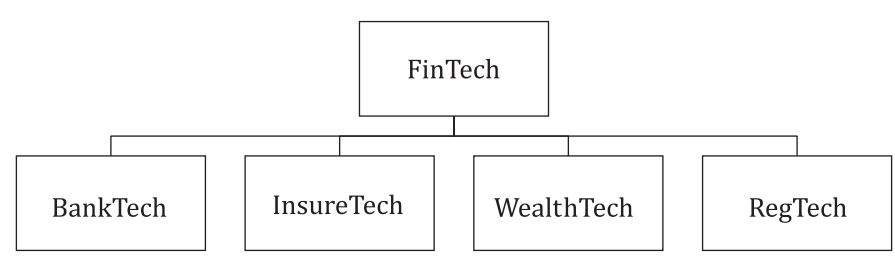

Źródło: opracowanie własne.

W tym miejscu warto rozważyć sens przedstawionej kategoryzacji. Szerokie spektrum zastosowań RegTech ma szansę wpisać się na stałe zarówno w sektor rządowy (np. usprawnić proces legislacyjny), jak i w sektor prywatny (zapewnić zgodność działania przedsiębiorcy z przepisami prawa). Sama technologia API gwarantuje spełnienie tej funkcji, aczkolwiek bez odpowiedniej infrastruktury telekomunikacyjnej i partnerstwa publiczno-prywatnego w tym zakresie rozwiązania RegTech będą cechować się hermetyzmem - będą zarezerwowane wyłącznie dla instytucji finansowych. Oprócz zastosowań stricte finansowych narzędzia RegTech mają szansę ułatwić obowiązki związane z szeregiem innych przepisów. Przykładowo mogą być to obowiązi wynikajace z polskiej ustawy o ochronie środowiska albo związane z identyfikacją czynów zabronionych w środowisku pracy (nadużycia finansowe) i automatycznym kierowaniem zawiadomień do organów ścigania. Istotnym argumentem prze-

${ }^{35}$ Ch. Chazot, Quoted in Institute of International Finance, RegTech: Exploring Solutions for Regulatory Challenges, Washington, DC: Institute of International Finance, October 2015, s. 2. 
mawiającym za wyodrębnieniem RegTech jako osobnej kategorii gospodarczej jest geneza rozwoju branży FinTech, ukierunkowanej przede wszystkim na podniesienie poziomu zaufania do instytucji finansowych po 2007 r. $^{36} \mathrm{Z}$ kolei założenia RegTech w dużej mierze opieraja się na tendencjach związanych z ograniczeniem kosztów compliance ${ }^{37}$. Warto również zauważyć, że działania RegTech są ukierunkowane na rozwój B2B w przeciwieństwie do sektora FinTech, który koncentruje się na działaniach skierowanych do konsumenta (B2C). W związku z tym rozwiązania RegTech mają szerokie zastosowanie i odnoszą się przede wszystkim do każdego przedsiębiorstwa, wzmacniając tym samym zdolność adaptacyjną nowych przepisów. Jeżeli uznamy powyższe twierdzenia za prawdziwe, to sektor RegTech stanowić będzie osobną gałąź prowadzenia działalności gospodarczej.

Organy administracji publicznej uważnie obserwują rozwój RegTech ${ }^{38}$. Państwa takie jak Stany Zjednoczone, Wielka Brytania czy Singapur rozpoczęły próby opracowywania nowego podejścia w tworzeniu regulacji z wykorzystaniem nowych technologii ${ }^{39}$. Sztuczna inteligencja i deep learning stanowia tylko dwa przykłady technologii IT, które automatyzują procesy zarządzania ryzykiem. Potencjał tych rozwiązań świadczy o tym, że z dużym prawdopodobieństwem zostaną zastosowane w ochronie praw konsumenta, nadzoru nad rynkiem i w regulacjach ostrożnościowych ${ }^{40}$. W Polsce zainteresowanie potencjałem RegTech wykazuje KNF. Świadczą o tym ostatnie działania podjęte przez Przewodniczącego KNF w postaci zawarcia umów o współpracy w zakresie FinTech ${ }^{41}$. Przykładowo przedmiotem umowy z Singapurem jest m.in. wzajemne przekazywanie rekomendacji odnośnie do podmiotów z sektora FinTech oraz udzielanie wsparcia spółkom FinTech w celu lepszego zrozumienia reżimu regulacyjnego w każdej z jurysdykcji. Współpraca z nadzorcami, którzy wypracowali pewne reguły postępowania, może przyczynić się do wypracowania określonych rozwiązań obniżajacych koszty compliance. Ważnym sygnałem ze strony polskiego nadzorcy jest powołanie osobnego departamentu w strukturach Urzędu Komisji Nadzoru Finansowego, który będzie prowadził analizy innowacji finansowych i segmentu FinTech ${ }^{42}$, czy też interdyscypli-

${ }^{36}$ Warto pamiętać, że FinTech nie zawsze jest kojarzony z etycznymi działaniami, koronnym przykładem jest tzw. High Frequency Trading.

${ }^{37}$ Institute of International Finance, RegTech: Exploring Solutions for Regulatory Challenges, <https://www.iif.com/topics/regtech/regtech-exploring-solutions-regulatory-challenges> [dostęp: 29.10.2015].

${ }^{38}$ K. Cukier, V. Mayer-Schönberger, Big Data: A Revolution that Will Transform How We Live, Work and Think, London 2013.

${ }^{39}$ M. Adams, Fintech: ASIC's Approach and Regulatory Issues, Paper Presented at the 21st Melbourne Money and Finance Conference ASIC, Further Measures to Facilitate Innovation in Financial Services, Consultation Paper 260, Australian Securities and Investments Commission 2016, s. 10-12.

${ }^{40}$ M. Najafabadi et al., Muharemagic, Deep Learning Applications and Challenges in Big Data Analytics, „Journal of Big Data” 2, 2015, s. 1-21.

${ }^{41}$ Zob. <https://www.knf.gov.pl/o_nas/komunikaty?articleId=61054\&p_id=18> [dostęp: 6.03.2018].

42 Zarządzenie nr 111 Prezesa Rady Ministrów w sprawie nadania statutu Urzędowi Komisji Nadzoru Finansowego z 5 października 2017 r. (M.P. 2017, poz. 947). 
narnego Zespołu Roboczego ds. Rozwoju Innowacji Finansowych. Rezultatem pracy zespołu roboczego jest raport ${ }^{43} \mathrm{z}$ listopada 2017 r., który pozwolił zidentyfikować najważniejsze bariery w zakresie rozwoju FinTech w Polsce oraz przedstawił szereg rekomendacji skierowanych do władz państwowych w celu usunięcia przedmiotowych barier. Wskazane działania nadzorcze pozwalaja wnioskować, że organy administracji publicznej próbują co raz lepiej zrozumieć zdygitalizowany biznes.

To, czym różni się zasadniczo RegTech od poprzednich lub aktualnych rozwiązań w głównej mierze opartych na ręcznym raportowaniu w procesie zarządzania ryzykiem compliance, jest zdolność do rzeczywistego przetwarzania danych i natychmiastowej reakcji na poszczególne zdarzenia. Rozbudowane narzędzia analiz danych tworzą zupełnie nowe podejście do zarządzania ryzykiem makroostrożnościowym. Polityka makroostrożnościowa koncentruje się na stabilności całego systemu finansowego, gdyż opiera się na całościowej analizie oraz na wzajemnych połączeniach i ewolucji w cza$\mathrm{sie}^{44}$. Regulacje wprowadzane przez poszczególnych ustawodawców coraz bardziej opierają się na normach techniczno-prawnych i tym samym przybieraja postać obowiązków prawnych opartych na metodach ilościowych. Tutaj RegTech może znaleźć zastosowanie w kontekście dostarczania informacji w czasie rzeczywistym. Tego typu podejście pozwoli na szybka reakcję ze strony regulatora i umożliwi natychmiastowe działanie organów państwa w przypadku naruszenia norm ostrożnościowych. Regulacje ostrożnościowe wymagaja od instytucji finansowych globalnego zrozumienia, monitorowania i raportowania wszystkich aspektów ich działalności organom nadzorczym w jurysdykcjach prawnych, w których prowadzą działalność. Wymogi makrostrożniościowe ulegają dynamicznym zmianom, przy czym raportowanie do wielu organów nadzorczych jest obecnie normą dla dużej instytucji finansowej działającej na skalę międzynarodowa ${ }^{45}$. Złożone zasady ustalania wielkości kapitału, dźwigni finansowej oraz normy płynnościowe poparte przeglądami okresowymi i testami warunków skrajnych (stress tests) zwiększają zapotrzebowanie na rozwiązania RegTech. W wyniku procesu analizy makroostrożnościowej powstaje zapotrzebowanie na duże zbiory danych oraz szybkie przetwarzanie. Na tym polu moga się sprawdzić rozwiązania big data. Nie bez znaczenia pozostaja wytyczne Komitetu Bazylejskiego w postaci zaleceń wynikających z BCBS $239^{46}$, określające wymogi dotyczące gromadzenia danych i ich właściwej „obróbki”. Warto zauważyć, że Europejski Bank Centralny prowadzi wstępne rozpoznanie możliwych rozwiązań RegTech w tym zakresie ${ }^{47}$.

\footnotetext{
${ }^{43}$ Raport $z$ prac Zespołu roboczego ds. rozwoju innowacji finansowych (FinTech), listopada 2017.

${ }^{44}$ International Monetary Fund, Financial Stability Board \& Bank for International Settlements, Elements of Effective Macroprudential Policy, 2016.

${ }^{45}$ Deloitte, Top Regulatory Trends for 2016 in Banking, 2015.

${ }^{46}$ Principles for Efective Risk Data Aggregation and Risk Reporting.

${ }^{47}$ Financial Stability Board, Elements of Efective Macroprudential Policies, 2016, <http:// www.fsb.org/2016/08/elements-of-e ective-macroprudential-policies> [dostęp: 31.08.2016].
} 


\section{Schemat 3}

Kluczowe obszary RegTech w świetle compliance

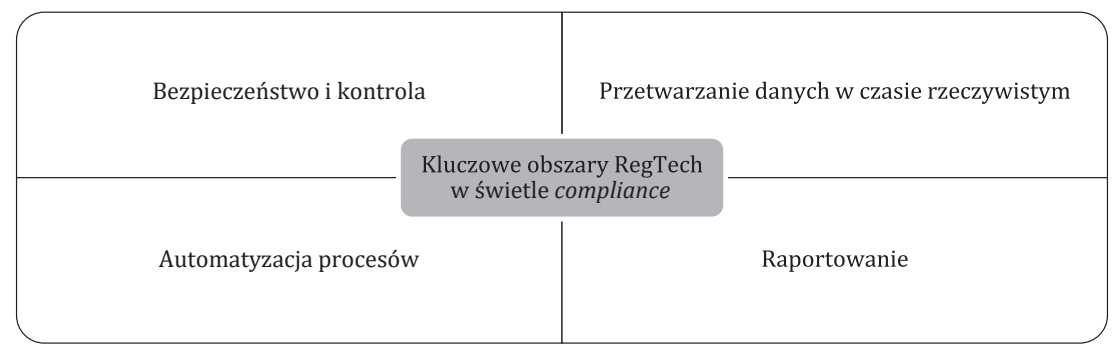

Źródło: opracowanie własne.

Obszar cyberbezpieczeństwa stanowi największe pole do dalszego rozwoju regulacyjnego, a co za tym idzie, głównego katalizatora rozwoju dla RegTech. Ponieważ branża usług finansowych nadal ewoluuje w kierunku cyfryzacji przemysłu opartego na danych, istnieje zwiększone ryzyko ataku, kradzieży lub oszustwa ze strony cyberprzestępców. Tego typu zdarzenia sa poważnym zagrożeniem dla stabilności systemu finansowego, a także całego państwa ${ }^{48}$. W świetle ostatnich wydarzeń w Stanach Zjednoczonych bezpieczeństwo danych stanowi poważny problem ${ }^{49}$. Cyberatak na bank centralny w Bangladeszu w 2016 r. przeprowadzony z wykorzystaniem systemu SWIFT wykazał słabe punkty istniejących struktur, a niedawne włamania na serwery Plus Banku i upublicznienie danych klientów dostarczają dalszych dowodów na istnienie potencjalnego ryzyka. Obszar bezpieczeństwa informatycznego wymaga gruntownych reform, które z dużym prawdopodobieństwem zostaną wprowadzone za pomoca państwowych regulacji. Pewne wypracowane standardy bezpieczeństwa moga zostać ubrane w przepisy ustaw. Przykładowo, zgodnie z wymogami bezpieczeństwa, banki sa zobligowane do prowadzenia tzw. testów penetracyjnych sieci w celu wykrycia potencjalnych luk w bezpieczeństwie sieci. Tego typu działania mogą zostać zautomatyzowane, a raportowanie od razu dostarczone regulatorowi z wykorzystaniem sztucznej inteligencji i rozwiązań chmurowych.

Wytyczne AML/KYC ${ }^{50}$ ustanowione przez FATF ${ }^{51}$ i Komitet Bazylejski, a następnie wdrażane na całym świecie przez krajowe organy sa siłą napędową popytu na rozwiązania RegTech - w szczególności rozwiązania IT automatyzujące procesy zapewniające zgodność, w tym identyfikowanie i raportowanie o podejrzanych transakcjach. Ważnym elementem w tej dziedzinie jest weryfikacja tożsamości klientów, co skutkuje wysokimi kosztami. Szerokie

48 S. Dahlgren, Importance of Addressing Cybersecurity Risks in the Financial Sector (Speech, OpRisk North America Annual Conference, New York City, 2015).

$49 \mathrm{~Np}$. RussiaGate albo Cambridge Analytica.

50 AML - Anti-Money Laundering, KYC - Know Your Customer.

51 FATF - Financial Action Task Force. 
zastosowanie na tym polu znajduje biometria. Pozostaje pytanie, jakie metody uwierzytelnienia będą spełniać wymogi stawanie przez regulacje. Do najpopularniejszych rozwiązań w tej dziedzinie można zaliczyć odciski palców, siatkówkę oka, a nawet uśmiech. Proces związany z identyfikacją tożsamości, weryfikacji dochodów lub źródeł funduszy jest zwykle ustanawiany i wdrażany za pomocą wewnętrznych systemów IT. Połączenie instytucji finansowej z organami nadzoru lub ścigania za pomoca protokołu API ułatwi wymianę i integrację danych. Dualne podejście związane ze zgłaszaniem podejrzanych transakcji (subiektywne - nietypowe zachowanie, obiektywne - progi ilościowe) są podstawowym wymogiem AML. Tego typu działania wymagaja zatrudnienia znacznego personelu. Rozwiązania oparte na sztucznej inteligencji sa $\mathrm{w}$ stanie sprostać wymaganiom dotyczacym raportowania incydentów. Istotne znaczenie może mieć nowe podejście w procesie weryfikacji klienta z KYC na KYD (know your data). To z kolei może doprowadzić do powstania zupełnie nowego paradygmatu tworzenia regulacji finansowych.

\section{ZAKOŃCZENIE I WNIOSKI}

Inflacja prawa finansowego, rozwój nowych technologii oraz fragmentaryzacja podmiotów rynków finansowych wymusza od ich uczestników nowego zarządzania kosztami compliance. Z perspektywy technologicznej RegTech znajduje szerokie zastosowanie w procesie redukcji tych kosztów. Główne ograniczenie rozwoju RegTech jest determinowane brakiem zdolności organów regulacyjno-nadzorczych do obsługi i przetwarzania danych generowanych przez instytucje finansowe. Inflacja prawa finansowego, tworzenie jednolitych rynków finansowych oraz cyfrowa gospodarka stanowią bodźce do rozwiązań o charakterze uniwersalnym. Ponieważ ryzyko compliance dotyczy coraz bardziej skomplikowanej analizy danych opartych na metodach ilościowych, w niedalekiej przyszłości można się spodziewać wprowadzenia ujednoliconych narzędzi do zapewnienia zgodności w postaci np. otwartego kodu źródłowego udostępnianego zainteresowanym podmiotom z wykorzystaniem API.

mgr Artur Pięta

Uniwersytet Ekonomiczny w Poznaniu

artur.pieta@ue.poznan.pl

\section{REGULATORY TECHNOLOGIES AS A CHANCE OF REDUCING THE COST OF MANAGING NON-COMPLIANCE}

$$
\text { Sum mary }
$$

The aim of the article is to present regulatory technology (RegTech) solutions and its possible application in the context of compliance costs optimisation. The author outlined the main trends (in global and domestic terms) that influence the rise in legal inflation and increase the compli- 
ance risk in financial institutions. The data that have been presented confirm the problematic overregulation of the market and reduction in the efficiency of doing business in highly developed markets. Further considerations describe the most important technologies affecting the development of the RegTech sector. An attempt was made to define regulatory technology and describe its possible impact on particular elements of compliance management. 
